\title{
Enhanced organic matter degradation by a sediment microbial fuel cell using hexavalent chromium as an electron acceptor
}

\author{
Yong-Yan Niu, Aman Khan, Zheng-Jun Chen, Shuai Zhao, Ke-Jia Wu, Xing-Peng Xiao and Xiang-Kai Li* \\ Key Laboratory of Cell Activities and Stress Adaptations, School of Life Sciences, Lanzhou University, 222 Tianshuinanlu, Lanzhou, Gansu \\ 730000, China
}

\begin{abstract}
In this study, a sediment microbial fuel cell (SMFC) system for the simultaneous biodegradation of organic matter and detoxification of hexavalent chromium $\mathrm{Cr}(\mathrm{VI})$ was investigated. The total organic carbon (TOC) removal rate of the SMFC with Cr(VI) was $30.07 \%$, which was signicantly higher than that in a SMFC without $\mathrm{Cr}(\mathrm{VI})(13.74 \%)$. In the SMFC with $\mathrm{Cr}(\mathrm{VI})$, the maximum values of open-circuit voltage (OCV) and power density were $408 \mathrm{mV}$ and $4.8 \mathrm{~mW} / \mathrm{m}^{2}$, respectively. During the long-term operation of the SMFC with $\mathrm{Cr}(\mathrm{VI}), 25 \mathrm{mg} / \mathrm{L}$ of $\mathrm{Cr}(\mathrm{VI})$ were completely reduced from all four consecutive batches over 48 days. MiSeq sequencing revealed that the biofilm microbial community of the anode comprised of Bacteroidetes (42.9\%), Proteobacteria (33.6\%), Chloroflexi (7.5\%), and Euryarchaeota (7.5\%) as the predominant phyla. Compared with that of the sediment, certain families were enriched; they included Pseudomonadaceae (46.88-fold), Flavobacteriaceae (5.05-fold), and Syntrophaceae (4.48-fold), which are organic matter-degrading bacteria. These results suggest that SMFCs are useful for TOC removal and detoxification of heavy metals in remediation of contaminated lakes. Keywords:sediment microbial fuel cell, TOC removal, hexavalent chromium removal, detoxification, microbial communities
\end{abstract} *Correspondence to:
Xiang-Kai Li, Key Laboratory of Cell Activities and Stress Adaptations, School of Life Sciences, Lanzhou University, 222 Tianshuinanlu, Lanzhou, Gansu
730000, China; E-mail: xkli@1zu.edu.cn

Received: November 25, 2016; Accepted: August 27, 2017; Published Online: January 17, 2018

Citation: Niu, Y.Y., Khan, A., Chen, Z.J., Zhao, S., Wu, K.J., Xiao, X.P. and Li, X.K., 2017, Enhanced organic matter degradation by a sediment microbial fuel cell using hexavalent chromium as an electron acceptor. Applied Environmental Biotechnology, 3(1), 1-9. http://doi.org/10.26789/AEB.2018.01.001. Copyright: Enhanced organic matter degradation by a sediment microbial fuel cell using hexavalent chromium as an electron acceptor. (C) 2018 Yong-Yan Niu et al.. This is an Open Access article distributed under the terms of the Creative Commons Attribution-Noncommercial 4.0 International License, permitting all non-commercial use, distribution, and reproduction in any medium, provided the original work is properly cited and acknowledged.

\section{Introduction}

Owing to rapid industrialization and urbanization, both sediments and water bodies are contaminated with heavy metals, polycyclic aromatic hydrocarbons (PAHs), and organic substances (Pu et al., 2017; Qu and Fan, 2010). In June 2011, a serious chromium slag contamination event occurred at Qujing in Yunan Province. A total of 5222.38 tons of hazardous chromium slags were illegally disposed of in the local reservoir, resulting in a reservoir hexavalent chromium (Cr(VI)) concentration of $200 \mathrm{mg} / \mathrm{L}$, which is 2000 times higher than the standard concentration (Gao and Xia, 2011). Subsequently, $300000 \mathrm{~m}^{3}$ of $\mathrm{Cr}(\mathrm{VI})$-polluted water was discharged into the Nanpan River (the source of the Pearl River), and the outlet groundwater $\mathrm{Cr}(\mathrm{VI})$ concentration increased to $2.24 \mathrm{mg} / \mathrm{L}$ (242 times the standard concentration (Gao and Xia, 2011; Pu et al., 2017). Previous studies have proved that $\mathrm{Cr}(\mathrm{VI})$ is highly soluble, mobile, mutagenic, and carcinogenic, and exposure to it increases the risk of asthma and cancers of the respiratory system (Mahmoud and El-Twab, 2017). However, organic substances, including alkylphenol polyethoxylates (APEs), polychlorinated biphenyls (PCBs), and PAHs, are also adsorbed by the aquatic sediment. In 2008, total PAH concentrations in the sediment of the Lanzhou Reach of the Yellow River ranged from 464 to $2621 \mathrm{ng} / \mathrm{g}$ dry weight (Xu et al., 2007). High concentra- tions of organic matter cause a sharp increase in water algae populations and the growth of aquatic plants, so that water ventilation and levels of dissolved oxygen are reduced; the oxygen-free layer may even be destroyed, which prevents the diffusion of pollutants from the sediment to the overlying water (Xu et al., 2015b). The technologies used to remove total organic carbon (TOC) from lake sediment include traditional physical and chemical methods (dredging, ozonation, and electrochemical degradation) and new biological methods (phytoremediation, bio-manipulation, and plant and microbe interaction) (Li and Yu, 2015; Qu and Fan, 2010). Several systems have been developed to treat $\mathrm{Cr}(\mathrm{VI})$ pollution in particular. They include pilot-scale ion exchange columns, a magnetic hybrid adsorbent, a byproduct of magnesium-based wet flue gas desulfurization, and nano-scale zero-valent iron particles (Cruz et al., 2017; Fang et al., 2017; Korak et al., 2017; Shang et al., 2017). There is no doubt that these methods have many advantages, such as high removal rate or rapid reaction rate. However, there are few reports on the simultaneous biodegradation of organic matter and $\mathrm{Cr}(\mathrm{VI})$ detoxification in polluted lakes.

Recently, the sediment microbial fuel cell (SMFC) has attracted significant attention owing to its unique ability to accelerate organic matter biodegradation in contaminated sediment or soil (Yan et al., 2012). A wide range of complex organic compounds, such as naphthalene, acenaphthene, 
and phenanthrene, can be degraded in the SMFC anode (Sherafatmand and $\mathrm{Ng}, 2015$ ). Certain microbes are capable of simultaneously remediating organic matter and heavy metal pollutants. Such microbes include Pseudomonas gessardii (strain LZ-E), which can degrade $77 \%$ of naphthalene with an initial concentration of $800 \mathrm{mg} / \mathrm{L}$ and reduce $95 \%$ of $\mathrm{Cr}(\mathrm{VI})$ with an initial concentration $10 \mathrm{mg} / \mathrm{L}$ (Huang et al., 2016). The simultaneous degradation of organic matter and the reduction of heavy metals by microbes can be simulated in a microbial fuel cell (MFC) by accelerating the transmission of electrons. Wang et al. (2012) constructed an MFC and increased total chemical oxygen demand (COD) removal in algal organic matter from $23 \pm 4 \%$ to $81 \pm 6 \%$. Another MFC technology was used to reduce the $\mathrm{Cr}(\mathrm{VI})$ content of electroplating wastewater by $99.5 \%$ (Li et al., 2008). However, there have been few studies on the use of SMFCs for simultaneous organic matter biodegradation and $\mathrm{Cr}(\mathrm{VI})$ reduction in polluted lakes.

Compared with oxygen, the most common electron acceptor in MFC, $\mathrm{Cr}(\mathrm{VI})$ has higher oxidation potential $(1.33 \mathrm{~V}$ vs $1.23 \mathrm{~V}$, determined using a standard hydrogen electrode) under acidic conditions (Yang et al., 2015), and Cr(VI) can be used as an electron acceptor in the cathode of a microbial fuel cell (MFC). Therefore, the MFC is an efficient novel technology for $\mathrm{Cr}(\mathrm{VI})$ reduction (Xafenias et al., 2013), and is able to completely remove an initial concentration of 100 $\mathrm{mg} / \mathrm{L} \mathrm{Cr}(\mathrm{VI})$ over $150 \mathrm{~h}$ (at an initial pH of 2) (Wang et al., 2008). Removal rates of $99.5 \%$ and $66.2 \%$ were obtained for $\mathrm{Cr}(\mathrm{VI})$ and total chromium, respectively, during a $25 \mathrm{~h} \mathrm{MFC}$ treatment, and increasing the initial concentration of $\mathrm{Cr}(\mathrm{VI})$ enhanced the power density (Li et al., 2008). However, little information is available on the use of SMFCs for the simultaneous detoxification of $\mathrm{Cr}(\mathrm{VI})$ and the biodegradation of organic matter of polluted lakes. In the present study, an SMFC system was set up for the simultaneous enhancement of organic matter degradation in the anode, and reduction of $\mathrm{Cr}(\mathrm{VI})$ in the cathode, with $\mathrm{Cr}(\mathrm{VI})$ as the electron acceptor. The inoculation sediment was collected upstream of the Lanzhou Reach on the Yellow River. We monitored the removal of TOC and $\mathrm{Cr}(\mathrm{VI})$, the generation of electricity, the microbial communities of the raw sediment, and the SMFC anode. Long-term SMFC operation was stable and effective, suggesting that SMFCs are useful for the in situ bioremediation of $\mathrm{Cr}(\mathrm{VI})$ contaminants and organic pollutants of lakes.

\section{Materials and Methods}

\subsection{Sample Collection}

Sediment and freshwater samples were collected from a sewage drain exit near the Yellow River in Lanzhou $\left(36^{\circ} 06 \mathrm{~N}, 103^{\circ} 39 \mathrm{E}\right)$. The soil samples were collected from $10 \mathrm{~cm}$ beneath the surface and stored at $4{ }^{\circ} \mathrm{C}$ until required.

\subsection{SMFC Construction and Operation}

The SMFCs were constructed in 1-L beakers, which were loaded with $0.5 \mathrm{~L}$ of sediment and covered with $0.5 \mathrm{~L}$ of stream water. Graphite rods were used for the electrodes. The graphite rods had a surface area of $54.26 \mathrm{~cm}^{2}$ (diameter: $1.6 \mathrm{~cm}$; length: $10 \mathrm{~cm}$ ), and the anode contained two graphite rods linked by copper wire. The cathode was placed $4 \mathrm{~cm}$ above the sediment-water interface, and contained one graphite rod. The anode and cathode were connected by copper wire with an external resistance of $1000 \Omega$ (Figure 1). The operation temperature of the SMFCs was maintained at $20 \pm$ $5^{\circ} \mathrm{C}$.

Four treatments were tested as follows: (1) Cr-SMFC: $25 \mathrm{mg} / \mathrm{L}$ of $\mathrm{Cr}(\mathrm{VI})$ was added to the cathode; (2) $\mathrm{O}_{2}$-SMFC contained no $\mathrm{Cr}(\mathrm{VI})$ in the cathode; (3) the open-circuit Cr-SMFC contained $\mathrm{Cr}(\mathrm{VI})$ but the circuit was broken; (4) the sterilized closed-circuit Cr-SMFC contained Cr(VI), and the sediment and water had been sterilized at $121^{\circ} \mathrm{C}$ for $1 \mathrm{~h}$. The long-term SMFCs were constructed in 3-L beakers, which were loaded with $1.5 \mathrm{~L}$ of sediment, covered with $1.5 \mathrm{~L}$ of stream water, and operated for 48 days. The voltage of resistance was recorded using a multimeter. The polarization and power curves were measured at an external resistor load varying from 100 to $10000 \Omega$, and the voltage at each resistor value was recorded when it reached a pseudo steady state (Hong et al., 2009a).

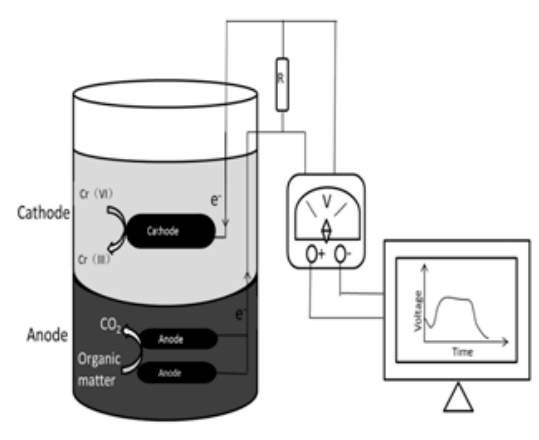

Figure 1. Schematic of the sediment microbial fuel cell (SMFC) reactor.

\subsection{Analytical Methods}

The TOC of the sediment was measured using a TOC solid state matrix analyzer (vario EL cube, Elementar Analysysteme GmbH, Germany). The TOC of the samples was expressed as a percentage of TOC removed (Adelaja et al.,2017). The voltage was converted into current according to Ohm's law, as described previously (Gee and Bauder, 1986). The concentration of $\mathrm{Cr}(\mathrm{VI})$ was determined using the 1,5-diphenylcarbazide method at $540 \mathrm{~nm}$, and was measured using a UV/VIS spectrophotometer (Lu et al., 2006). The $\mathrm{Cr}(\mathrm{VI})$ content in $1 \mathrm{~g}$ of water-soil surface soil was washed with 25 $\mathrm{mL}$ of phosphate-buffered saline (PBS) ( $\mathrm{pH} 7.0$ ), and determined using the 1,5-diphenylcarbazide method. Nature withering the soil before and after washed by PBS, respectively. Following acid digestion, the content of $\mathrm{Cr}$ (III) and the total chromium content of $1 \mathrm{~g}$ of dry soil were determined by atomic absorption spectrome- 
try (Miao et al., 2015). Anode biofilm formation was investigated by scanning electron microscopy (SEM). Please refer to previous research for the details of sample preparation (Zhang et al., 2006). Finally, the samples were freeze-dried and sputter-coated with gold, then investigated by SEM (S-3400, HITACHI, Japan).

\subsection{Extraction and MiSeq Sequencing of $16 \mathrm{~S}$ rRNA Gene Amplicons}

After use, the anode of the SMFC was washed with phosphatebuffered saline to collect the microorganisms; the resulting liquid was centrifuged at $7104 \times g$ for $10 \mathrm{~min}$. DNA was extracted from $0.25 \mathrm{~g}$ (wet weight) of the raw sediments and from the anode biofilm using a PowerSoil DNA Isolation Kit (MO BIO, USA). The DNA concentration and quality were determined using a NanoDrop 2000 spectrophotometer (Thermo, China). Extracted DNA was diluted to $10 \mathrm{ng} / \mu \mathrm{L}$ and stored at $-20^{\circ} \mathrm{C}$ for downstream use. Universal primers 515F (5'-GTGCCAGCMGCCGCGGTAA-3') and 909R (5'-CCCCGYCAATTCMTTTRAGT-3'), with unique $12 \mathrm{nt}$ barcodes at the 5'-end of $515 \mathrm{~F}$ were used to amplify the V4-V5 hypervariable region of the $16 \mathrm{~S}$ rRNA gene. Annealing temperatures and polymerase chain reaction (PCR) amplification procedures have been described previously (Wu et al., 2016). Replicate PCRs were carried out for each sample; the products were tested by $1 \%$ agarose gel electrophoresis and purified using a SanPrep Column DNA Gel Extraction Kit (Sangon Biotech, Shanghai, China). The sequencing samples were prepared using a TruSeq DNA kit, according to the manufacturer's instructions. The purified library was diluted, denatured, re-diluted, and mixed with PhiX (equal to $30 \%$ of the final DNA amount), as described in the Illumina library preparation protocols, and then presented to the Illumina MiSeq system for sequencing with the MiSeq Reagent Kit v2 $(2 \times 250 \mathrm{bp})$ at the Environmental Genome Platform of the Chengdu Institute of Biology.

\subsection{Statistical Analysis}

The TOC results were subjected to statistical analysis using SPSS software (SPSS 16.0, Duncan, USA). $P<0.01$ was considered significant.

\section{Results and Discussion}

\subsection{TOC Removal from Sediment}

The sediment used in this study was heavily contaminated with organic materials and heavy metals. The initial TOC was $2.2 \%$ (Table 1), and after 48 days, the three treatments applied (Cr-SMFC, $\mathrm{O}_{2}$-SMFC, and open-circuit Cr-SMFC) had removed $30.07 \%, 13.74 \%$, and $7.84 \%$ of the TOC, respectively (Figure 2).

This data is consistent with previous studies showing that SMFCs can enhance the biodegradation of organic matter (Xu et al., 2015a; Yang et al., 2015). The low rate of oxygen reduction in the cathodes and electron transfer are the major limitations of the SMFC application. Our data showed that as an electron acceptor, $\mathrm{Cr}$ (VI) can increase the TOC removal rate by $30.07 \%$, which is higher than the TOC degradation rate $(22.1 \%)$ attributable to long-term SMFC use (operation for 2 years) (Yang et al., 2015). With Cr-SMFC, the electrons from the organic matter biodegradation in the anode chamber are transferred to the cathode electrode, and are then immediately accepted by the $\mathrm{Cr}(\mathrm{VI})$. Therefore, the presence of $\mathrm{Cr}(\mathrm{VI})$ in the cathode stimulates electron transmission and TOC removal by the SMFC. However, TOC removal using the Cr-SMFC system in the present study (30.07\%) was lower than that using an SMFC with Fe(III) oxide $(57.19 \%$ $\pm 1.52 \%$ ) (Xu, et al., 2017). The explanation for this observation might be that $\mathrm{Cr}(\mathrm{VI})$ is highly toxic to microbial communities (Arshad et al., 2017). Moreover, Fe(II) can be re-oxidized to $\mathrm{Fe}(\mathrm{III})$ by bacteria for recycling $(\mathrm{Xu}$, et al., 2017). This would explain the higher rates of TOC removal obtained using the SMFC with Fe(III) oxide compared with the $\mathrm{Cr}$-SMFC system; $\mathrm{Cr}$ (VI) was irreversibly reduced to trivalent chromium ( $\mathrm{Cr}(\mathrm{III})$ ). However, considering that the annual discharge of Cr slag in China is 450,000 $\mathrm{t}$ (Gao and $\mathrm{Xia}, 2011), \mathrm{Cr}(\mathrm{VI})$ is an ideal candidate for an electron acceptor in SMFC cathodes designed to enhance organic matter degradation.

Table 1. Baseline analysis of contaminated sediments.

\begin{tabular}{lc}
\hline Parameter & value \\
\hline$p \mathrm{H}$ & 6.5 \\
Total organic carbon $(\%)$ & $2.21 \%$ \\
& $\mathrm{mg} / \mathrm{kg}$ \\
Rapidly available potassium & 17.9112 \\
Rapidly available phosphorus & 19.2618 \\
Copper & 31.828 \\
Zinc & 68.983 \\
Chromium & 144.216 \\
Nickel & 58.71 \\
\hline
\end{tabular}

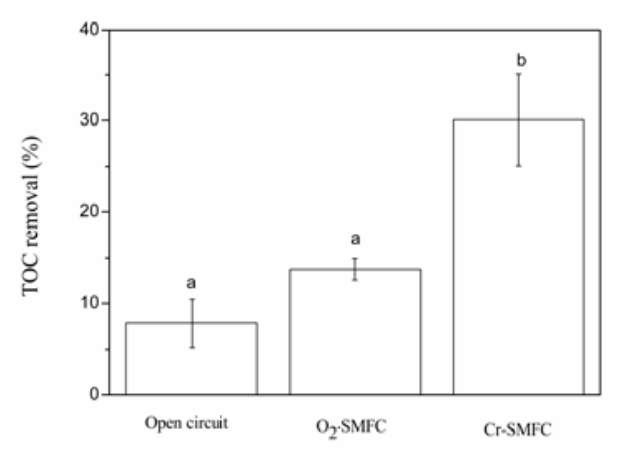

Figure 2. Total organic carbon (TOC) removal using the various sediment microbial fuel cells (SMFCs) for 48 days. Error bars represent the standard deviations from three tests. Significant differences $(P<0.01)$ between groups are indicated with letters above the bars.) reactor. 


\subsection{Electricity Generation and $\mathrm{Cr}(\mathrm{VI})$ Removal by SMFCs}

After a stable lag period of 11 days, $\mathrm{Cr}(\mathrm{VI})$ was added to the cathode. The voltage of the Cr-SMFC increased rapidly from 52 to $110.2 \mathrm{mV} 60 \mathrm{~h}$ after $\mathrm{Cr}(\mathrm{VI})$ addition, and then gradually decreased, whereas the $\mathrm{O}_{2}$-SMFC voltage remained at 50 $\mathrm{mV}$ throughout the experiment. Interestingly, no electricity was generated by the sterilized Cr-SMFC (Figure 3A). The polarization curve of $\mathrm{Cr}-\mathrm{SMFC}$ exhibited a maximum opencircuit voltage $(\mathrm{OCV})$ of $408 \mathrm{mV}$ and a maximum power density of $4.88 \mathrm{~mW} / \mathrm{m}^{2}$ (Figure 3B). The closed-circuit $\mathrm{Cr}$ SMFC removed Cr(VI) $100 \%$ more quickly than the opencircuit Cr-SMFC (64.1\%) over 16 days (Figure 4A). Total chromium removal was also faster with the closed-circuit Cr-SMFC than with the open-circuit Cr-SMFC (100\% vs $85.2 \%$ ) over 16 days (Figure 4B). After the experiment, we discovered that the soil in the water-soil interface of the closed-circuit Cr-SMFC contained $364.95 \mathrm{mg} / \mathrm{kg}$ of $\mathrm{Cr}$ (III) (compared with $267.80 \mathrm{mg} / \mathrm{kg}$ in the soil in the water-soil interface of the open-circuit $\mathrm{Cr}-\mathrm{SMFC}$ ).

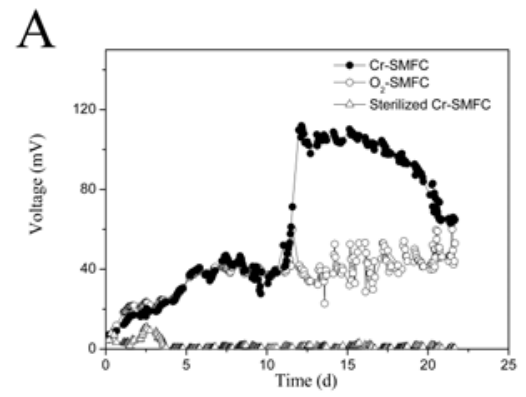

B

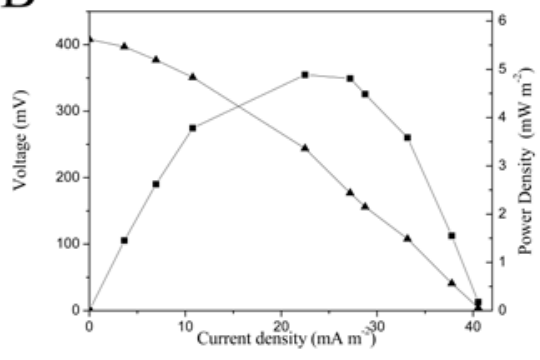

Figure 3. Electricity generation using the sediment microbial fuel cells (SMFCs). (A) Voltage generation in SMFCs with $\mathrm{Cr}(\mathrm{VI})$, without $\mathrm{Cr}(\mathrm{VI})$, and with $\mathrm{Cr}(\mathrm{VI})$ plus sterilization, with an external resistance of $1000 \Omega$. (B) Polarization and power density curves.

Electron acceptors play an important role in MFC electricity generation (You et al., 2006); most use oxygen, but this is complicated by low solubility, and SMFC operation has generally depended on aeration or a rotating cathode to improve the oxygen content (Xu, et al., 2017). This increases the required energy input and operating costs. $\mathrm{Cr}(\mathrm{VI})$ is a practicable electron acceptor with high solubility and oxidation potential (Tandukar et al., 2009). The voltage of the Cr-SMFC increased by $57.8 \mathrm{mV}$ immediately after the addition of $\mathrm{Cr}(\mathrm{VI})$, which may have been due to a cathode potential increase of 50-70 $\mathrm{mV}$ upon addition of $\mathrm{Cr}(\mathrm{VI})$ (Huang et al., 2010), promoting electron transfer between the anode and cathode. Although $\mathrm{Xu}$ added $\mathrm{Fe}$ (III) oxide to the sediment to achieve a higher TOC removal rate, the voltage of the SMFC decreased to $104 \mathrm{mV}$ because the Fe(III) oxide competed with the anode electrode for electrons (Xu, et al., 2017).

Previous researchers have proposed that a typical mechanism for the removal of $\mathrm{Cr}(\mathrm{VI})$ involves adsorption, coprecipitation, ion exchange, and subsequent reduction (Cruz et al., 2017; Fang et al., 2017; Korak et al., 2017; Shang et al., 2017). The use of MFCs is a popular method of treating wastewater containing $\mathrm{Cr}(\mathrm{VI})$ because the $\mathrm{Cr}(\mathrm{VI})$ is directly reduced to $\mathrm{Cr}(\mathrm{III})$, which is far less toxic form of chromium (Huang et al., 2010). Table 2 gives details of $\mathrm{Cr}(\mathrm{VI})$ remediation as reported in previous MFC studies, and reveals that SMFC has been underused for $\mathrm{Cr}(\mathrm{VI})$ remediation in the past. In contrast to conventional MFC, in SMFC the organic matter contained in the sediment acts as the electron donor rather than acetate (Huang et al., 2010) or lactate (Xafenias et al., 2013), resulting in lower operation costs. We demonstrated that $\mathrm{Cr}(\mathrm{VI})$ removal occurred more slowly in the open-circuit $\mathrm{Cr}$-SMFC than in the closed-circuit Cr-SMFC (Figure 4A and $\mathrm{B})$, suggesting that the production of electricity is an efficient $\mathrm{Cr}(\mathrm{VI})$ reduction pathway (Xafenias et al., 2015). Some of the $\mathrm{Cr}(\mathrm{VI})$ may be reduced to $\mathrm{Cr}(\mathrm{III})$ by acting as an electron acceptor in SMFC, as in previous MFC studies (Huang et al., 2010). Furthermore, soluble $\mathrm{Cr}$ (III) was undetectable in the catholyte, and the resultant $\mathrm{Cr}$ (III) was present as precipitated $\mathrm{Cr}(\mathrm{OH})_{3}$, which was adsorbed/or migrated from the cathode to the sediment in the present study (Figure 4C) (Huang et al., 2011). In this way, $\mathrm{Cr}(\mathrm{VI})$ is detoxified and stabilized in the sediment with minimum transfer to the water, hence our investigation of the use of SMFCs as a remediation technique for treating $\mathrm{Cr}(\mathrm{VI})$-contaminated lakes.

\subsection{Long-term Operation of the Cr-SMFC}

The Cr-SMFC was operated in 4 batches over 48 days at room temperature $\left(20 \pm 5^{\circ} \mathrm{C}\right)$. We detected a voltage increase immediately after the addition of $\mathrm{Cr}(\mathrm{VI})$, and the voltage decreased gradually in each batch as the $\mathrm{Cr}(\mathrm{VI})$ was depleted. The maximum voltage of each successive batch decreased slightly. This clearly demonstrates that large variations in voltage generation were dependent on the presence of $\mathrm{Cr}(\mathrm{VI})$ (Figure 5A). $\mathrm{Cr}(\mathrm{VI})$ removal reached $100 \%$ approximately every 12 days (Figure 5B).

Long-term MFCs have been investigated for electricity production and sludge and wastewater treatment (Ge et al., 2013; Zhang et al., 2015). An MFC has been operated for more than 110 days to produce electricity using dairy manure as a fuel (Zhang et al., 2015). Two 1.8-L MFCs have operated on sewage sludge for almost 500 days, and an MFC using primary sludge achieved better results than one using digested sludge (Ge et al., 2013). SMFCs are particularly 
Table 2. Comparison of microbial fuel cell (MFC) studies in $\mathrm{Cr}(\mathrm{VI})$ remediation.

\begin{tabular}{|c|c|c|c|c|c|c|}
\hline Anode inoculum & Cathode & $\begin{array}{c}\text { Initial } \\
\text { concentration }\end{array}$ & $\mathrm{Cr}(\mathrm{VI})$ reduction & $\begin{array}{l}\text { Electron } \\
\text { donor }\end{array}$ & $\begin{array}{c}\text { Cathodic } \\
\text { pH }\end{array}$ & References \\
\hline $\begin{array}{c}\text { Anaerobic } \\
\text { microorganisms }\end{array}$ & $\begin{array}{l}\mathrm{Cr}(\mathrm{VI}) \text {-containing } \\
\text { wastewater }\end{array}$ & $100 \mathrm{mg} / 1$ & $100 \%$ over $150 \mathrm{~h}$ & Acetate & 2 & (Wang et al., 2008) \\
\hline Anaerobic sludge & $\mathrm{Cr}(\mathrm{VI})$ & $204 \mathrm{mg} / 1$ & $99.5 \%$ over $25 \mathrm{~h}$ & Acetate & 2 & (Li et al., 2008) \\
\hline $\begin{array}{c}\text { Shewanella } \\
\text { oneidensis MR-1 }\end{array}$ & $\mathrm{Cr}(\mathrm{VI})$ & $10 \mathrm{mg} / \mathrm{l}$ & $100 \%$ over 3 days & Lactate & 8 & (Xafenias et al., 2013) \\
\hline Anaerobic sludge & $\mathrm{Cr}(\mathrm{VI})$ & $9.5 \mathrm{mg} / 1$ & $90 \%$ over 5 days & Acetate & $8.7-9.3$ & (Habibul et al., 2016) \\
\hline $\begin{array}{c}\mathrm{Cr}(\mathrm{VI}) \text {-contaminated } \\
\text { soil }\end{array}$ & $\begin{array}{l}\text { Biocathode+ } \\
\text { Cr(VI) }\end{array}$ & $39.2 \mathrm{mg} / \mathrm{l}$ & $100 \%$ over $7 \mathrm{~h}$ & Acetate & - & (Huang et al., 2010) \\
\hline $\begin{array}{l}\text { Mixed anaerobic } \\
\text { culture }\end{array}$ & $\begin{array}{l}\text { Biocathode+ } \\
\text { Cr(VI) }\end{array}$ & $20-70 \mathrm{mg} / 1$ & $100 \%$ over 7 days & Acetate & 7 & (Tandukar et al., 2009) \\
\hline Sediments & $\begin{array}{l}\text { River water } \\
\quad+\mathrm{Cr}(\mathrm{VI})\end{array}$ & $25 \mathrm{mg} / \mathrm{l}$ & $\begin{array}{c}100 \% \text { over } 14 \\
\text { days }\end{array}$ & $\begin{array}{l}\text { Organic of } \\
\text { sediments }\end{array}$ & 6.5 & - \\
\hline
\end{tabular}

suitable for long-term operation. Sediments accumulate significant biomass as well as organic contaminants, and are considered an energy reservoir (Xu et al., 2015). A 100-L SMFC has been in operation for over 2 years, and could theoretically continue to operate for up to 8.5 years without external electron donors (Yang et al., 2015). Compared with other MFCs, SMFCs are inexpensive because they do not require a proton exchange membrane (PEM), and are easy to operate over a range of temperatures $\left(10-30^{\circ} \mathrm{C}\right.$ ) (Hong et al., 2009b). A particular advantage of SMFCs is that they enable the simultaneous in situ treatment of both the sediment and overlaying water.

\subsection{Analysis of the Microbial Communities of the Cr-SMFC Anode and Sediment}

The electricity-generated biofilm was investigated by scanning electron microscopy. The anode surface was smooth and clean before the experiment commenced, but had a rough and porous surface after 47 days (Figure 6). MiSeq sequencing was used to determine the diversity of the SMFC microbial community. The basic sequencing parameters are shown in Table 3. The initial and Cr-SMFC sediments yielded 3,319 and 1,856 operational taxonomic units (OUTs), respectively. The Good's coverage estimator indicated that the library size was sufficient to cover $74-89 \%$ of the bacterial communities. The Shannon diversity index decreased from 10.282 in the raw sediment to 7.553 in the Cr-SMFC sediment. At the phylum level, Bacteroidetes accounted for $42.9 \%$ of the total composition of the Cr-SMFC biofilm, followed by Proteobacteria (33.6\%), Chloroflexi (7.5\%), Euryarchaeota (7.5\%), Firmicutes $(3.3 \%)$, and Spirochaetes $(2.5 \%)$. In the raw sediment, Proteobacteria accounted for $47.9 \%$, followed by Bacteroidetes (17.7\%), Chloroflexi (9.4\%), Firmicutes (8.2\%), and Euryarchaeota $(3.8 \%$; Figure $7 \mathrm{~A})$. The abundance of Bacteroidetes bacteria increased 2.5 times during Cr-SMFC treatment. In contrast, the abundance of Actinobacteria decreased after Cr-SMFC treatment (2.25 vs 0.81\%). Archaea from the phylum Euryarchaeota were also highly enriched by Cr-SMFC treatment (7.5 vs 3.8\%); they included members of the genera Methanospirillum, Methanobacterium, and Methanosaeta. Furthermore, 1.98-4.14\% of the reads could not be classified in any phylum, suggesting that they represent novel, uncultured bacterial strains. Families enriched after Cr-SMFC treatment included Pseudomonadaceae (46.88 times), Moraxellaceae (6.92 times), and Flavobacteriaceae (5.05 times) (Figure 7B). Flavobacterium was the most predominant genus $(0.31 \%)$ in the Cr-SMFC anode community (Figure 7C).

To date, more than 30 pure isolates have been reported in MFC research. However, mixed culture is better suited to practical applications such as wastewater treatment (Kim et al., 2007) and organic contaminant removal (Luo et al., 2015). The main phylum detected after Cr-SMFC treatment was Bacteroidetes, at a much higher percentage than in previous reports (42.9\%, compared with 9.5 (Wang et al., 2015) and $1.7-6.9 \%$ (Lu et al., 2015). Bacteroidetes specialize in degrading high-molecular weight organic matter (Thomas et al., 2011). Members of the phylum Proteobacteria constituted the second most abundant bacteria in this study, and are often enriched on MFC anodes used for current generation (Lu et al., 2015). Most exoelectrogens, such as Geobacter (Wang et al., 2015) and Pseudomonas (Jayapriya and Ramamurthy, 2012), belong to the phylum Proteobacteria. Flavobacterium $(0.31 \%)$ was the dominant genus observed and contains many species that can degrade harmful organic matter. Five representative strains that can degrade pentachlorophenol were assigned to the genus Flavobacterium. A Flavobacterium sp. that can degrade diazinon and parathion has also been isolated (Sethunathan and Yoshida, 1973). Several common electrogenic bacteria, including Geobacter (Bond and Lovley, 2003), Pseudomonas (Jayapriya and Ramamurthy, 

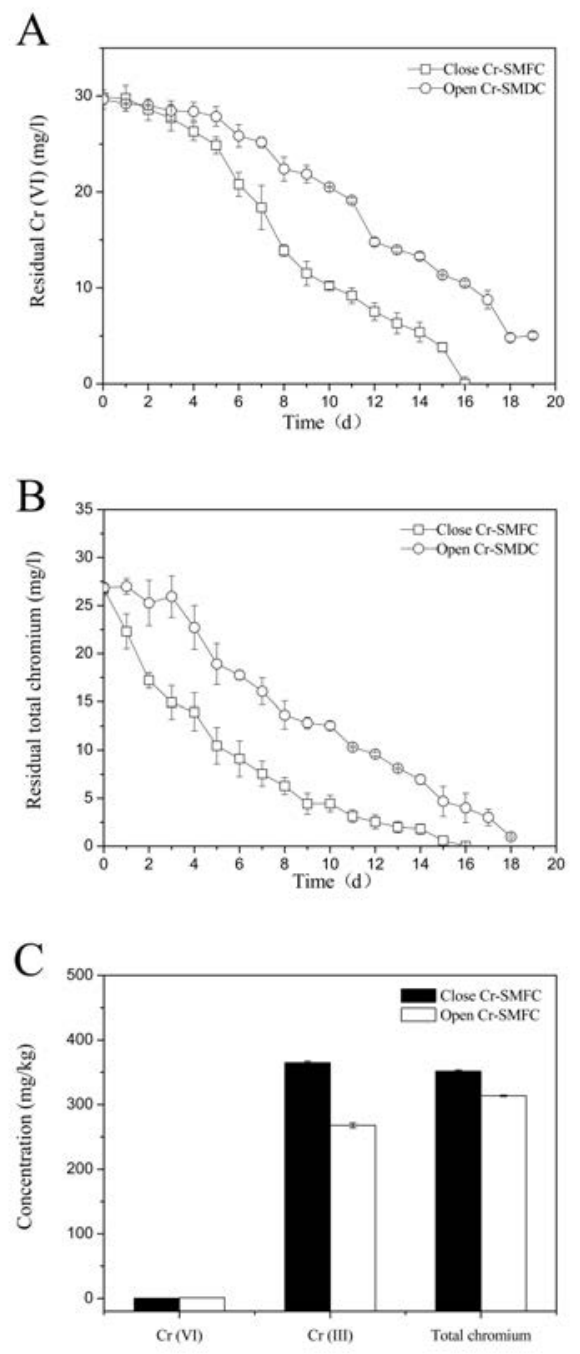

Figure 4. $\mathrm{Cr}(\mathrm{VI})$ removal using the sediment microbial fuel cells (SMFCs). (A) $\mathrm{Cr}$ (VI) removal in closed-circuit and open-circuit, Cr-SMFCs. (B) Total chromium removal in closed-circuit and open-circuit Cr-SMFCs. (C) Analysis of $\mathrm{Cr}(\mathrm{VI}), \mathrm{Cr}(\mathrm{III})$, and total chromium in the water-sediment surface soil.

2012), Desulfobacter (Zhao et al., 2008), and Rhodoferax (Chaudhuri and Lovley, 2003), were also observed in our study (Figure 7C). Moreover, some electrochemically active bacteria are $\mathrm{Cr}(\mathrm{VI})$ resistant and have strong $\mathrm{Cr}(\mathrm{VI})$ reducing activity, such as Geobacter metallireducens (Bond et al., 2002; Chovanec et al., 2012); Escherichia coli (Liu et al., 2010; Zhang et al., 2006), and Shewanella oneidensis MR1(Wang et al., 2014; Xafenias et al., 2013). Therefore, the presence of $\mathrm{Cr}(\mathrm{VI})$ may alter the microbial community of the anode and enrich the dominant species.

\section{Conclusion}

In this study, we used $\mathrm{Cr}(\mathrm{VI})$ as a novel electron acceptor in an SMFC cathode. TOC removal by the Cr-SMFC was enhanced 2.19 times compared with an SMFC without $\mathrm{Cr}(\mathrm{VI})$.

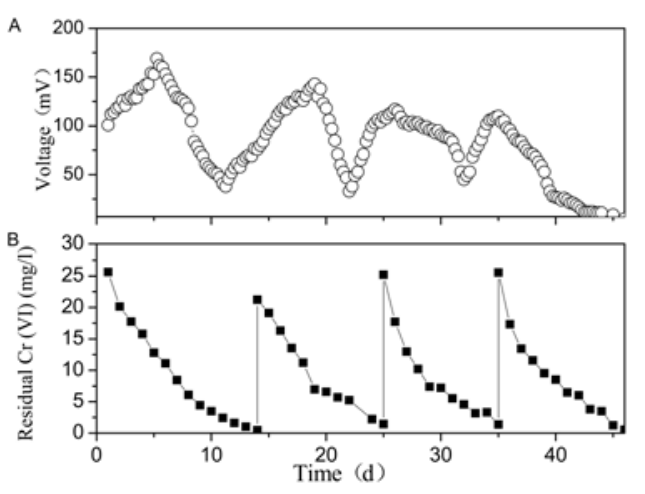

Figure 5. Long-term stability of the sediment microbial fuel cell (SMFC). (A) Voltage generation in an SMFC with a $\mathrm{Cr}(\mathrm{VI})$ concentration of $25 \mathrm{mg} / \mathrm{L}$ over 47 days. (B) $\mathrm{Cr}$ (VI) removal during 4 cycles of $\mathrm{Cr}$-SMFC use.
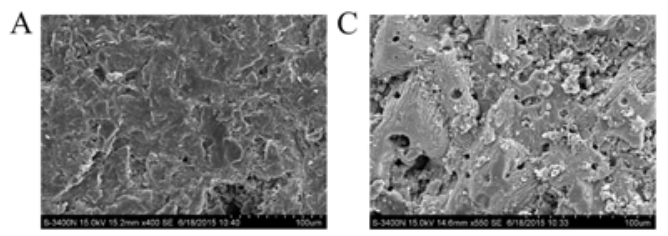

$\mathrm{B}$
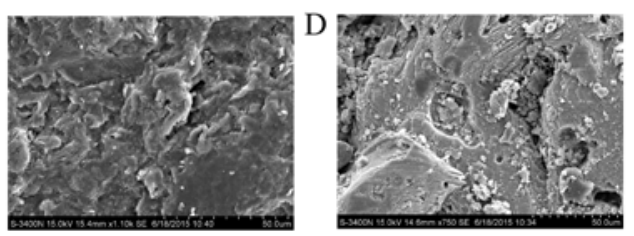

Figure 6. Scanning electron microscope images of anodes without microbes (A, B) and with microbes (C, D) at scales of 50 and $100 \mu \mathrm{m}$, respectively.

The maximum power density attained was $4.8 \mathrm{~mW} / \mathrm{m}^{2}$. During long-term operation, $\mathrm{Cr}(\mathrm{VI})$ removal reached $100 \%$ approximately every 12 days. Furthermore, the operation of the Cr-SMFC decreased microbial community diversity and enriched electrochemically active microorganisms in the anode, such as members of the phyla Bacteroidetes (42.9\%), Proteobacteria (33.6\%), and Chloroflexi (7.5\%). Therefore, SMFCs have the potential to simultaneously remove $\mathrm{Cr}(\mathrm{VI})$ and bioremediate organic-rich sediment in situ.

Table 3. Diversity indices calculated based on a cutoff of $97 \%$ similarity of 16S rRNA sequences of 9001 reads per sample.

\begin{tabular}{lccccc}
\hline Sample ID & PD_whole_tree & Chaol & Coverage & OUT-num & Shannon \\
\hline Sediment & 248.0703 & 9720.899 & 0.745 & 3319 & 10.282 \\
Cr-SMFC & 138.533 & 5180.054 & 0.8623 & 1856 & 7.5537 \\
\hline
\end{tabular}


A
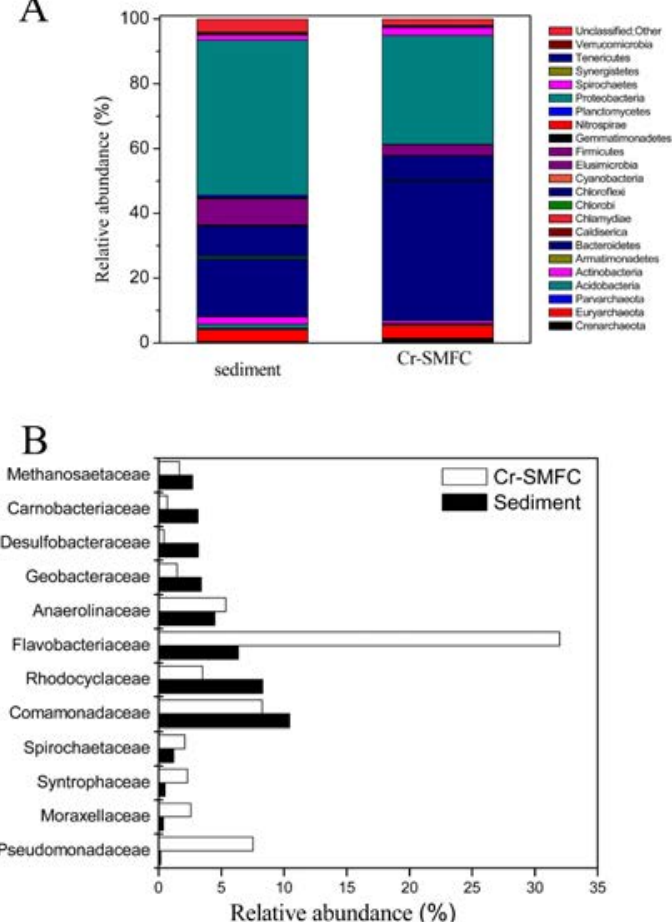

C

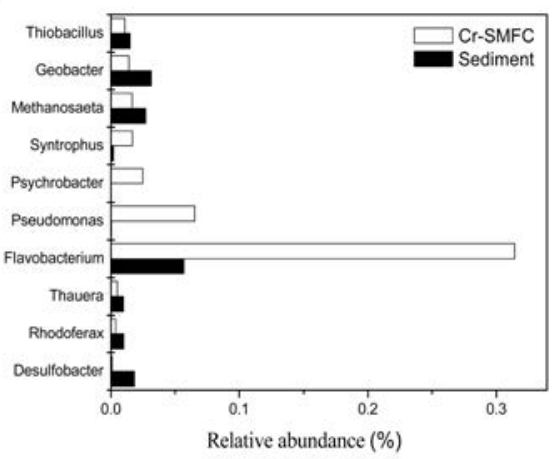

Figure 7. Taxonomic classification of bacterial DNA sequences from raw sediment and the Cr-SMFC anode at the (A) phylum, (B) class, and (C) genus levels.

\section{Acknowledgements}

The present study was supported by National Natural Science Foundation of China grants (numbers 31470224 and 31400430), a MOST international cooperation grant (number 2014DFA91340), and a Gansu Provincial International Cooperation grant (number 1504WKCA089-2).

\section{References}

Adelaja, O., Keshavarz, T., Kyazze, G. 2017. Treatment of phenanthrene and benzene using microbial fuel cells operated continuously for possible in situ and ex situ applications. International Biodeterioration \& Biodegradation, 116, 91-103. https://doi.org/10.1016/j.ibiod.2016.10.021
Arshad, M., Khan, A.H.A., Hussain, I., Badar-uz-Zaman, Anees, M., Iqbal, M., Soja, G., Linde, C., Yousaf, S. 2017. The reduction of chromium (VI) phytotoxicity and phytoavailability to wheat (Triticum aestivum L.) using biochar and bacteria. Applied Soil Ecology, 114, 90-98. https://doi.org/10.1016/j.apsoil.2017.02.021

Bond, D.R., Holmes, D.E., Tender, L.M., Lovley, D.R. 2002. Electrode-reducing microorganisms that harvest energy from marine sediments. Science, 295(5554), 483-485. https://doi.org/10.1126/science.1066771

Bond, D.R., Lovley, D.R. 2003. Electricity production by Geobacter sulfurreducens attached to electrodes. Applied and Environmental Microbiology, 69(3), 1548-1555. https://doi.org/10.1128/AEM.69.3.1548-1555.2003

Chaudhuri, S.K., Lovley, D.R. 2003. Electricity generation by direct oxidation of glucose in mediatorless microbial fuel cells. Nature Biotechnology, 21(10), 1229-1232. https://doi.org/ 10.1038/nbt867

Chovanec, P., Sparacino-Watkins, C.E., Zhang, N., Basu, P., Stolz, J. 2012. Microbial reduction of chromate in the presence of nitrate by three nitrate respiring organisms. Frontiers in Microbiology, 3, 416. https://doi.org/10.3389/fmicb.2012.00416

Cruz, D.R., Santos, B.T., Cunha, G.C., Româo, L.P. 2017. Green synthesis of a magnetic hybrid adsorbent $\left(\mathrm{CoFe}_{2} \mathrm{O}^{4} / \mathrm{NOM}\right)$ : Removal of chromium from industrial effluent and evaluation of the catalytic potential of recovered chromium ions. Journal of Hazardous Materials, 334, 76-85. https://doi.org/10.1016/j.jhazmat.2017.03.062

Fang, D., Zhang, X., Dong, M., Xue, X., 2017. A novel method to remove chromium, vanadium and ammonium from vanadium industrial wastewater using a byproduct of magnesiumbased wet flue gas desulfurization. Journal of Hazardous Materials,336, 8-20. https://doi.org/10.1016/j.jhazmat.2017.04.048

Gao, Y. and Xia, J., 2011. Chromium contamination accident in China: viewing environment policy of China. Environmental Science and Technology-Columbus, 45(20), 8605. https://www. dx.doi.org/10.1021/es203101f

Ge, Z., Zhang, F., Grimaud, J., Hurst, J. and He, Z., 2013. Long-term investigation of microbial fuel cells treating primary sludge or digested sludge. Bioresource Technology, 136(136C), 509-514. https://doi.org/10.1016/j.biortech.2013.03.016

Gee, G.W. and Bauder, J.W., 1986. Particle-size analysis. pp. $383-$ 441. In: Klute A (ed), Methods of Soil Analysis: Part I (Second edition), Agronomy Monograph, vol. 9, ASA and SSSA, Madison, WI, USA.

Habibul, N., Hu, Y., Wang, Y.K., Chen, W., Yu, H.Q. and Sheng, G.P., 2016. Bioelectrochemical chromium (VI) removal in plant-microbial fuel cells. Environmental Science \& Technology, 50(7), 3882-3889. https://doi.org/10.1021/acs.est.5b06376

Hong, S.W., Chang, I.S., Choi, Y.S. and Chung, T.H., 2009a. Experimental evaluation of influential factors for electricity harvesting from sediment using microbial fuel cell. Bioresource Technology, 100(12), 3029-35. https://doi.org/10.1016/j.biortech.2009.01.030

Hong, S.W., Chang, I.S., Yongsu, C. and Taihak, C. 2009b. Experimental evaluation of influential factors for electricity harvesting from sediment using microbial fuel cell. Bioresource Technology, 100(12), 3029-3035. https://doi.org/10.1016/j.biortech.2009.01.030 
Huang, H., Wu, K., Khan, A., Jiang, Y., Ling, Z., Liu, P., Chen, Y., Tao, X. and Li, X., 2016. A novel Pseudomonas gessardii strain LZ-E simultaneously degrades naphthalene and reduces hexavalent chromium. Bioresource Technology, 207, 370-378. https://doi.org/10.1016/j.biortech.2016.02.015

Huang, L., Chai, X., Chen, G. and Logan, B.E., 2011. Effect of set potential on hexavalent chromium reduction and electricity generation from biocathode microbial fuel cells. Environmental Science \& Technology, 45(11), 5025-5031. https://doi.org/10.1021/es103875d

Huang, L., Chen, J., Quan, X. and Yang, F., 2010. Enhancement of hexavalent chromium reduction and electricity production from a biocathode microbial fuel cell. Bioprocess and Biosystems Engineering, 33(8), 937-945. https://doi.org/10.1007/s00449-010-0417-7

Jayapriya, J. and Ramamurthy, V., 2012. Use of non-native phenazines to improve the performance of Pseudomonas aeruginosa MTCC 2474 catalysed fuel cells. Bioresource Technology, 124, 23-28. https://doi.org/10.1016/j.biortech.2012.08.034

Kim, B.H., Chang, I.S. and Gadd, G.M., 2007. Challenges in microbial fuel cell development and operation. Applied Microbiology and Biotechnology, 76(3), 485-494. https://doi.org/10.1007/s00253-007-1027-4

Korak, J.A., Huggins, R. and Arias-Paic, M., 2017. Regeneration of pilot-scale ion exchange columns for hexavalent chromium removal. Water Research, 118, 141-151. https://doi.org/10.1016/j.watres.2017.03.018

Li, W.W. and Yu, H.Q., 2015. Stimulating sediment bioremediation with benthic microbial fuel cells. Biotechnology Advances, 33(1), 1-12.

https://www.dx.doi.org/10.1016/j.chemosphere.2006.10.074

Li, Z., Zhang, X. and Lei, L., 2008. Electricity production during the treatment of real electroplating wastewater containing $\mathrm{Cr}^{6+}$ using microbial fuel cell. Process Biochemistry, 43(12), $1352-1358$ https://doi.org/10.1016/j.procbio.2008.08.005

Liu, G., Yang, H., Wang, J., Jin, R., Zhou, J. and Lv, H., 2010. Enhanced chromate reduction by resting Escherichia coli cells in the presence of quinone redox mediators. Bioresource Technology, 101(21), 8127-8131. https://doi.org/10.1016/j.biortech.2010.06.050

Lu, A., Zhong, S., Chen, J., Shi, J., Tang, J. and Lu, X., 2006. Removal of $\mathrm{Cr}(\mathrm{VI})$ and $\mathrm{Cr}(\mathrm{III})$ from aqueous solutions and industrial wastewaters by natural clino-pyrrhotite. Environmental Science \& Technology, 40(9), 3064-3069.

https://doi.org/ 10.1021/es052057x

Lu, L., Xing, D. and Ren, Z.J., 2015. Microbial community structure accompanied with electricity production in a constructed wetland plant microbial fuel cell. Bioresource Technology, 195, 115-121. https://doi.org/10.1016/j.biortech.2015.05.098

Luo, J., Li, M., Zhou, M. and Hu, Y., 2015. Characterization of a novel strain phylogenetically related to Kocuria rhizophila and its chemical modification to improve performance of microbial fuel cells. Biosensors and Bioelectronics, 69, 113120. https://doi.org/10.1016/j.bios.2015.02.025

Mahmoud, A.M. and El-Twab, S.M.A., 2017. Caffeic acid phenethyl ester protects the brain against hexavalent chromium toxicity by enhancing endogenous antioxidants and modulating the JAK/STAT signaling pathway.
Biomedicine \& Pharmacotherapy, 91, 303-311. https://www. dx.doi.org/ 10.1016/j.biopha.2017.04.073

Miao, Y., Liao, R., Zhang, X.-X., Wang, Y., Wang, Z., Shi, P., Liu, B. and Li, A., 2015. Metagenomic insights into $\mathrm{Cr}(\mathrm{VI})$ effect on microbial communities and functional genes of an expanded granular sludge bed reactor treating high-nitrate wastewater. Water Research, 76, 43-52. https://doi.org/10.1016/j.watres.2015.02.042

$\mathrm{Pu}, \mathrm{C}$., Addai, B., Pan, X. and Bo, P., 2017. Securitization product design for China's environmental pollution liability insurance. Environmental Science and Pollution Research, 24(4), 3336-3351. https://www. dx.doi.org/10.1007/s11356-016-8172-1

Qu, J. and Fan, M., 2010. The current state of water quality and technology development for water pollution control in China. Critical Reviews in Environmental Science and Technology, 40(6), 519-560. https://www. dx.doi.org/10.1080/10643380802451953

Sethunathan, N. and Yoshida, T., 1973. A Flavobacterium sp. that degrades diazinon and parathion. Canadian Journal of Microbiology, 19(7), 873-875. https://doi.org/ 10.1139/m73-138

Shang, J., Zong, M., Yu, Y., Kong, X., Du, Q. and Liao, Q., 2017. Removal of chromium (VI) from water using nanoscale zerovalent iron particles supported on herb-residue biochar. Journal of Environmental Management, 197, 331e337. https://doi.org/10.1016/j.jenvman.2017.03.085

Sherafatmand, M. and Ng, H.Y., 2015. Using sediment microbial fuel cells (SMFCs) for bioremediation of polycyclic aromatic hydrocarbons (PAHs). Bioresource Technology, 195, 122130. https://doi.org/10.1016/j.biortech.2015.06.002

Tandukar, M., Huber, S.J., Onodera, T., Pavlostathis, S.G., 2009. Biological chromium (VI) reduction in the cathode of a microbial fuel cell. Environmental Science \& Technology, 43(21), 8159-8165. https://doi.org/10.1021/es9014184

Thomas, F., Hehemann, J.H., Rebuffet, E., Czjzek, M. and Michel, G., 2011. Environmental and Gut Bacteroidetes: The Food Connection. Frontiers in Microbiology, 2(93), 93. https://doi.org/10.3389/fmicb.2011.00093

Wang, C., Chen, J., Hu, W.J., Liu, J.-Y., Zheng, H.L. and Zhao, F., 2014. Comparative proteomics reveal the impact of Om$\mathrm{cA} / \mathrm{MtrC}$ deletion on Shewanella oneidensis MR-1 in response to hexavalent chromium exposure. Applied Microbiology and Biotechnology, 98(23), 9735-9747. https://doi.org/10.1007/s00253-014-6143-3

Wang, G., Huang, L. and Zhang, Y., 2008. Cathodic reduction of hexavalent chromium [Cr(VI)] coupled with electricity generation in microbial fuel cells. Biotechnology Letters, 30(11), 1959. https://doi.org/10.1007/s10529-008-9792-4

Wang, H., Liu, D.M., Lu, L., Zhao, Z.W., Xu, Y.P. and Cui, F.Y., 2012. Degradation of algal organic matter using microbial fuel cells and its association with trihalomethane precursor removal. Bioresource Technology, 116(7), 80-85. https://doi.org/10.1016/j.biortech.2012.04.021

Wang, H., Qu, Y., Li, D., Zhou, X. and Feng, Y., 2015. Evaluation of an integrated continuous stirred microbial electrochemical reactor: Wastewater treatment, energy recovery and microbial community. Bioresource Technology, 195, 89-95. https://doi.org/10.1016/j.biortech.2015.06.039 
Wu, W., Huang, H., Ling, Z., Yu, Z., Jiang, Y., Liu, P. and Li, $X ., 2016$. Genome sequencing reveals mechanisms for heavy metal resistance and polycyclic aromatic hydrocarbon degradation in Delftia lacustris strain LZ-C. Ecotoxicology, 25(1), 234-247. https://doi.org/10.1007/s10646-015-1583-9

Xafenias, N., Zhang, Y. and Banks, C.J., 2013., Enhanced performance of hexavalent chromium reducing cathodes in the presence of Shewanella oneidensis MR-1 and lactate. Environmental Science \& Technology, 47(9), 4512-4520. https://doi.org/10.1021/es304606u

Xafenias, N., Zhang, Y. and Banks, C.J., 2015. Evaluating hexavalent chromium reduction and electricity production in microbial fuel cells with alkaline cathodes. International Journal of Environmental Science and Technology, 12(8), 2435-2446. https://doi.org/ 10.1007/s13762-014-0651-7

Xu, B., Ge, Z. and He, Z., 2015. Sediment microbial fuel cells for wastewater treatment: challenges and opportunities. Environmental Science: Water Research \& Technology, 1(3), 279-284. https://doi.org/10.1039/C5EW00020C

Xu, J., Yu, Y., Wang, P., Guo, W., Dai, S. and Sun, H., 2007. Polycyclic aromatic hydrocarbons in the surface sediments from Yellow River, China. Chemosphere, 67(7), 1408-1414. https://www. dx.doi.org/10.1016/j.chemosphere.2006.10.074

$\mathrm{Xu}$, X., Zhao, Q. and Wu, M.S., 2015a. Removal and changes of sediment organic matter and electricity generation by sediment microbial fuel cells and amorphous ferric hydroxide. Chemical and Biochemical Engineering Quarterly Journal, 28(4), 561-566. https://doi.org/10.15255/CABEQ.2014.2029

Xu, X., Zhao, Q. and Wu, M.S., 2015b. Improved biodegradation of total organic carbon and polychlorinated biphenyls for electricity generation by sediment microbial fuel cell and surfactant addition. RSC Advances, 5(77), 62534-62538. https://www. dx.doi.org/10.1039/C5RA12817J
Xu, X., Zhao, Q., Wu, M., Ding, J. and Zhang, W., 2017. Biodegradation of organic matter and anodic microbial communities analysis in sediment microbial fuel cells with/without Fe(III) oxide addition. Bioresource Technology, 225, 402-408. https://doi.org/10.1016/j.biortech.2016.11.126

Yan, Z., Song, N., Cai, H., Tay, J.H. and Jiang, H., 2012. Enhanced degradation of phenanthrene and pyrene in freshwater sediments by combined employment of sediment microbial fuel cell and amorphous ferric hydroxide. Journal of Hazardous Materials, 199, 217-225. https://doi.org/10.1016/j.jhazmat.2011.10.087

Yang, Y., Lu, Z., Lin, X., Xia, C., Sun, G., Lian, Y. and Xu, M., 2015. Enhancing the bioremediation by harvesting electricity from the heavily contaminated sediments. Bioresour Technology, 179, 615-618. https://doi.org/10.1016/j.biortech.2014.12.034

You, S., Zhao, Q., Zhang, J., Jiang, J. and Zhao, S., 2006. A microbial fuel cell using permanganate as the cathodic electron acceptor. Journal of Power Sources, 162(2), 1409-1415. https://doi.org/10.1016/j.jpowsour.2006.07.063

Zhang, G., Zhao, Q., Jiao, Y. and Lee, D.J., 2015. Long-term operation of manure-microbial fuel cell. Bioresource Technology, $180,365-369$.

https://doi.org/10.1016/j.biortech.2015.01.002

Zhang, T., Cui, C., Chen, S., Ai, X., Yang, H., Shen, P. and Peng, Z., 2006. A novel mediatorless microbial fuel cell based on direct biocatalysis of Escherichia coli. Chemical Communications, (21), 2257-2259. https://doi.org/10.1039/b600876c

Zhao, F., Rahunen, N., Varcoe, J.R., Chandra, A., Avignone-Rossa, C., Thumser, A.E. and Slade, R.C., 2008. Activated carbon cloth as anode for sulfate removal in a microbial fuel cell. Environmental Science \& Technology, 42(13), 4971-4976. https://doi.org/10.1021/es8003766 